\title{
Extravasation of contrast beneath the preputial skin due to improper technique of retrograde urethrogram
}

\author{
Siddharth Pandey, Deepanshu Sharma, Gaurav Garg, Ajay Aggarwal
}

Department of Urology, King George's Medical University, Lucknow, India

Correspondence to Dr Gaurav Garg, gougarg@gmail.com

Accepted 29 June 2018
D Check for updates

(c) BMJ Publishing Group Limited. No commercial re-use. See rights and permissions. Published by BMJ.

To cite: Pandey S, Sharma D, Garg G, et al. BMJ Case Rep Published Online First: [please include Day Month Year]. doi:10.1136/bcr-2018225822

\section{DESCRIPTION}

A 22-year-old uncircumcised male patient had a thin stream of urine and had to exert pressure while voiding. He had a history of some instrumentation in his penis during childhood, but no records were available. He was first seen by a primary care physician, who made a provisional diagnosis of stricture urethra and advised for a retrograde urethrogram (RUG). His RUG had a contrast shadow, which was thought to be possible dilated distal urethra due to proximal obstruction (stricture), and the patient was referred to us for further management (figure 1). When we examined the patient, he was found to have phimosis. A dorsal slit was done and the meatus was examined, which was normal. A gentle calibration was done with a $14 \mathrm{~F}$ Foley catheter that was normal. He voided with a good stream after surgery. The radio-opaque shadow that was seen on the RUG was nothing but the extravasated contrast between the preputial skin and glans penis.

RUG is the best imaging modality for evaluating the urethra in men. ${ }^{1}$ A RUG is done with the patient positioned obliquely at 45 degrees. The bottom leg is flexed at the knee joint (90 degrees) and the top leg is kept straight. The meatus has to be cleaned with an antiseptic solution and clearly visualised and then a $12 \mathrm{~F}$ or $14 \mathrm{~F}$ Foley catheter is inserted with the balloon placed at the fossa navicularis.

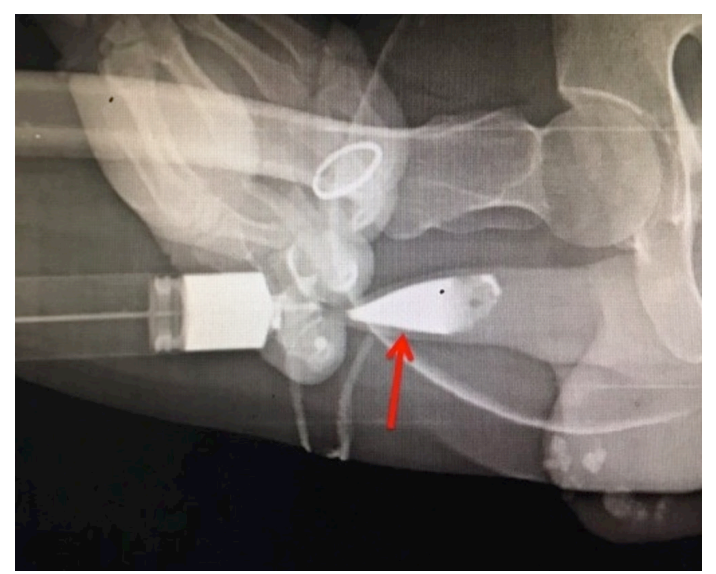

Figure 1 Retrograde urethrogram showing contrast being instilled but has extravasated beneath the preputial skin (arrow). Although the patient positioning is proper as described in the text, the catheter was not placed properly in the urethra and it appears that the stretch is applied over the preputial skin rather than the penis as whole.
The balloon is inflated with 1 to $1.5 \mathrm{~mL}$ distilled water and then $20-30 \mathrm{~mL}$ of water-soluble contrast solution is instilled into the urethra with the penis kept at a mild stretch. Then the X-ray film is taken. ${ }^{2}$ Any deviation from the proper technique leads to improper interpretation of the RUG. In the present case, the patient had phimosis and the catheter was misplaced and the contrast extravasated in the space between the preputial skin and glans. Also, whenever there is a patient with such a presentation, it is imperative that the penis is examined for entities such as phimosis and meatal stenosis. These are readily apparent on clinical examination and therefore the patient is spared from unnecessary investigations. In cases with phimosis, if a concurrent urethral pathology is suspected, then it is better to do a dorsal slit or circumcision first so that the meatus is adequately visualised for doing a proper RUG.

\section{Learning points}

In patients with any voiding lower urinary tract symptoms, it is imperative that the penis should be examined clinically to look for abnormalities such as phimosis and meatal stenosis.

- When doing a retrograde urethrogram (RUG), proper technique has to be followed.

- In uncircumcised patients, if there is inadequate preputial retraction due to phimosis, it is better to do a circumcision or dorsal slit before proceeding with RUG.

Contributors SP conceived the case report. SP and DS were major contributors towards writing the manuscript. GG, AA and SP treated the patient and also interpreted the patient data. SP and GG were involved in the review. All authors read and approved the final manuscript.

Funding The authors have not declared a specific grant for this research from any funding agency in the public, commercial or not-for-profit sectors.

Competing interests None declared.

Patient consent Obtained.

Provenance and peer review Not commissioned; externally peer reviewed.

\section{REFERENCES}

1 Kawashima A, Sandler CM, Wasserman NF, et al. Imaging of urethral disease: a pictorial review. Radiographics 2004;24 Suppl 1-S195-S216.

2 Breyer BN, Cooperberg MR, McAninch JW, et al. Improper retrograde urethrogram technique leads to incorrect diagnosis. J Urol 2009;182:716-7. 
Copyright 2018 BMJ Publishing Group. All rights reserved. For permission to reuse any of this content visit http://group.bmj.com/group/rights-licensing/permissions.

BMJ Case Report Fellows may re-use this article for personal use and teaching without any further permission.

Become a Fellow of BMJ Case Reports today and you can:

- Submit as many cases as you like

- Enjoy fast sympathetic peer review and rapid publication of accepted articles

Access all the published articles

- Re-use any of the published material for personal use and teaching without further permission

For information on Institutional Fellowships contact consortiasales@bmjgroup.com

Visit casereports.bmj.com for more articles like this and to become a Fellow 